\title{
In vitro evaluation of force degradation of elastomeric chains used in Orthodontics
}

André Weissheimer1, Arno Locks², Luciane Macedo de Menezes³, Adriano Ferreti Borgatto ${ }^{4}$, Carla D'Agostini Derech ${ }^{5}$

Objective: To analyze the in vitro force degradation of four different brands of elastomeric chains: American Orthodontics, Morelli, Ormco and TP Orthodontics. Methods: The sample consisted of 80 gray elastomeric chains that were divided into four groups according to their respective manufacturers. Chain stretching was standardized at 21 $\mathrm{mm}$ with initial force release ranging from $300 \mathrm{~g}$ to $370 \mathrm{~g}$. The samples were kept in artificial saliva at a constant temperature of $37^{\circ} \mathrm{C}$ and the degradation force was recorded at the following time intervals: initial, 1, 3, 5, 7 and 9 hours, and 1, 7, 14,21, 28, and 35 days. Results: There was a statistically significant difference between the groups regarding the force degradation, mainly within the first day, as a force loss of 50-55\% was observed during that time in relation to the initial force. The force delivered at 35 days ranged from $122 \mathrm{~g}$ to $148 \mathrm{~g}$. Conclusion: All groups showed force degradation over time, regardless of their trademarks, a force loss of 59-69\% was observed in the first hour compared to baseline. However, because the variation in force degradation depends on the trademark, studies such as the present one are important for guiding the clinical use of these materials.

Keywords: Elastomers. Shear bond strength. Biomedical and dental materials.

Objetivo: analisar, in vitro, a degradação de força, ao longo do tempo, de elastômeros das marcas comerciais American Orthodontics, Morelli, Ormco e TP Orthodontics. Métodos: a amostra constituiu-se de 80 segmentos de elastômeros em cadeia fechada na cor cinza, divididos em quatro grupos, conforme o fabricante. A distensão foi padronizada em $21 \mathrm{~mm}$, com liberação de força inicial variando de 300 a $370 \mathrm{~g}$ de força. As amostras foram mantidas em saliva artificial em temperatura constante de $37^{\circ} \mathrm{C}$, e a força avaliada nos seguintes intervalos: inicial, 1h, 3h, 5h, 7h, 9h, 1 dia, 7 dias, 14 dias, 21 dias, 28 dias e 35 dias. Resultados: houve diferença estatisticamente significativa na degradação de força entre os grupos avaliados, sendo que no primeiro dia houve perda de 50 a 55\% em relação à força inicial. Os valores médios de força em 35 dias variaram de 122 a 148g. Conclusão: todas as marcas comerciais apresentaram degradação de força ao longo do tempo, sendo que na primeira hora a perda de força esteve entre 59 e $69 \%$ da força inicial. Porém, como existe variação dessa degradação dependendo da marca comercial, estudos como esses são importantes para orientação do uso desses elastômeros.

Palavras-chave: Elastômeros. Resistência à tração. Materiais biomédicos e odontológicos.

${ }^{1} \mathrm{PhD}$ Student in Orthodontics, PUC-RS.

${ }^{2}$ Professor of Orthodontics, UFSC.

${ }^{3}$ Professor of Orthodontics, PUC-RS.

${ }^{4}$ Professor of Statistics, UFSC.

${ }^{5}$ Professor of the Specialization Course in Orthodontics, UFSC.
How to cite this article: Weissheimer A, Locks A, Menezes LM, Borgatto AF, Derech CA. In vitro evaluation of force degradation of elastomeric chains used in Orthodontics. Dental Press J Orthod. 2013 Jan-Feb; 18(1):55-62.

Submitted: May 13, 2009 - Revised and accepted: October 2, 2010

" The authors report no commercial, proprietary or financial interest in the products or companies described in this article.

Contact address: Carla D'Agostini Derech

Av. Rio Branco, 333/306 - Centro - CEP: 88.015-201 - Florianópolis/SC - Brazil E-mail: carladerech@hotmail.com 


\section{INTRODUCTION}

Elastomers are materials that have the ability to quickly return to their original size after substantial deformation, acting similarly to the coil spring. They are structurally classified as polymers, i.e., materials which are characterized by the formation of a repeating chain with simpler chemical structure. Since they are thermoplastic, it is possible to create devices with different shapes. ${ }^{5}$

They are widely used in promoting dental movement, correction of rotations, midline discrepancies, space closure, canine distalization and dental arch constriction. ${ }^{1,4,6}$ The main advantages are: They are easy to handle, patient cooperation is not required, and they are comfortable, hygienic and economic. ${ }^{4,7}$

However, the forces released by these materials are unstable and alter due to time, the addition of dyes, chain configuration (open or closed), pre-stretch, speed and amount of stretch, the oral environment, saliva, enzymes, changes in $\mathrm{Ph}$, exposure to light, air, water, ozone, oxidants, food, chemical hygiene and the physical action of chewing and tooth brushing. . $^{811,13,15,16,18-22,25}$

In Orthodontics, synthetic elastomers are polymers based on polyurethane, with superior physicochemical properties than those derived from natural rubber. The derivatives of polyurethane elastomers, after chemical reaction which causes polymerization, present as a shapeless mass, with polymeric chains presenting relatively weak forces of attraction between them. The vulcanization process is then used to improve the mechanical properties of the material through the lateral union between chains by covalent cross-linking. Thus, three-dimensional structures are formed, converting the flexible product into a resistant material, elastic, with lower solubility to organic solvents and greater resistance to deterioration by heat, light and natural aging. Another phenomenon responsible for improving the final properties of these materials is assigned to tie points distributed along the polymer formed by linear chains, called cross virtual chains. ${ }^{17}$ These chains are non-covalent chemical bonds formed within the same molecule or between different molecules. Chemically are referred to as hydrogen bonding and van der Waals forces. ${ }^{10}$ What makes this information important is the fact that the power assigned to the material, which is from virtual cross-links, is not obtained by the addition of loads as in conventional rubber, but chemically determined by the internal composition of materials. This internal composition is determined by the technology, the refinement of the technique and the quality of raw materials used in the manufacture of this material. ${ }^{17}$ Therefore, the final quality of the elastomer critically depends on the manufacturing process, which makes the conduction of periodic surveys essential to verify the quality and the physical properties behavior of the elastomeric chains available on the market.

Therefore, the objective of this study was to evaluate in vitro the magnitude of the force degradation of different elastomeric chains of four trademarks.

\section{MATERIAL AND METHODS}

Eighty gray elastomeric chain segments were evaluated in the closed configuration, divided into four groups of different brands, each with 20 segments:

" Am Group (Memory chain; ref.: 854-252, American Orthodontics, Sheboygan, WI, USA);

» Mo Group (Short gray Rubber chain, ref.: 60.05.501 - Morelli, Sorocaba, SP, Brazil);

" Or Group (Power chain generation II, ref.: 639-0001, Ormco Corporation, Glendora, CA, USA) and

" TP Group (E-chain, ref.: 383-050, TP Orthodontics Inc, La Porte, IN, USA).

It was standardized that the elastomeric chain segments were drawn to a distance of $21 \mathrm{~mm}$, producing average initial force of $318.85 \mathrm{~g} / \mathrm{f}$. Thus, the required number of links in each elastomeric chains to produce such strength, varied according to the manufacturer (Table 1). However, the stretching of elastomeric segments in the chain did not exceed $50 \%$ of its original length because they can generate excessive forces. ${ }^{15}$

The elastomers tested were kept in their original packaging until the moment of testing. To avoid possible damage to the structure of the elastomeric chain during the cutting procedure, the same was done in the half of the next link that was not part of the elastomeric chain to be analyzed. Eighty maintainer devices were made to keep the elastomeric chain segments stretched at a distance of $21 \mathrm{~mm}$ throughout the experiment. The devices were attached to acrylic plates and placed in plastic containers with artificial saliva at a constant temperature of $37^{\circ} \mathrm{C}\left(98.6^{\circ} \mathrm{F}\right)$ (Fig 1). 
To assess the behavior of the elastomeric chains, a universal mechanical testing machine (Instron Corporate - Norwood, MA, USA) was configured to stretch the elastomeric chains with a constant speed of $50 \mathrm{~mm} / \mathrm{min}$ to the distance of $21 \mathrm{~mm}$. Each segment of the elastomer was pulled to the ends of the machine and stretched to $21 \mathrm{~mm}$. After 15 seconds, the time needed for stabilization of the material, the initial force value was recorded.

Next, the samples were carefully transferred to the maintainer device, which returned to the acrylic plate and immersed in artificial saliva at $37^{\circ} \mathrm{C}\left(98.6^{\circ} \mathrm{F}\right)$.

For subsequent measurements, the universal testing machine was programmed to maintain fixed at 21 $\mathrm{mm}$ the distance between their edges (Fig 2). Next, the elastomers were placed on the device, and the force values were recorded after 5 seconds. $^{7}$ Again the elas- tomeric chains were transferred to the maintainer, and stored under the conditions described above, until the next measurement. Besides the initial measurement, the samples were evaluated at intervals of 1, 3, 5, 7, 9 and 24 hours, and 7, 14, 21, 28 and 35 days.

The 15 seconds waiting to record the initial force was adopted as a result of fluctuations in the value of the force after the initial stretching of the elastomeric chains. After that time, the force value remained stable allowing its registration. During the revaluation of elastomeric chains, the time required to stop the force stabilization was 5 seconds.

To assess the different behaviors of the elastomeric chain according to the time, we used the Analysis of Variance (ANOVA), according to a completely randomized design with factorial arrangement and further tested the normal distribution of data. The $\mathrm{F}$ test was

Table 1 - Characterization of sample groups, with the number of links before stretching, original length without stretching (in millimeters), amount of stretching (in millimeters and in percentage), till the extent of $21 \mathrm{~mm}$.

\begin{tabular}{|c|c|c|c|}
\hline Group & Number of links & Initial (mm) & Stretching ( $\mathrm{mm} / \%$ ) \\
\hline $\mathrm{Am}$ & 5 & 14.5 & $6.5 / 44.8$ \\
\hline Mo & 7 & 17.5 & $3.5 / 20.0$ \\
\hline Or & 5 & 14.5 & $6.5 / 44.8$ \\
\hline $\mathrm{TP}$ & 6 & 15.5 & $5.5 / 35.4$ \\
\hline
\end{tabular}

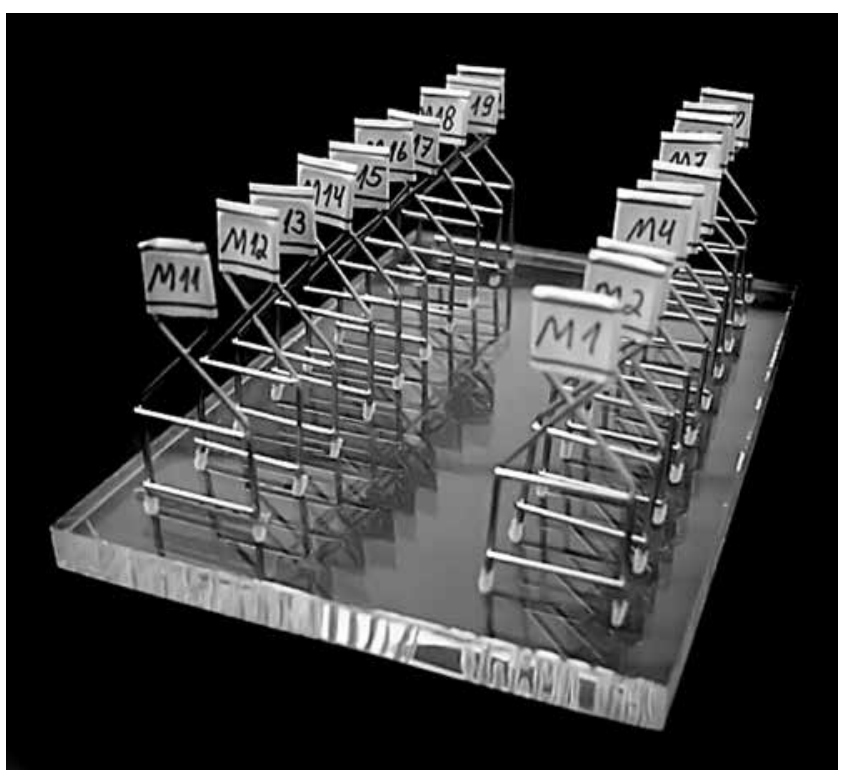

Figure 1 - Maintainer devices, attached to an acrylic plate, with tips fixed at a distance of $21 \mathrm{~mm}$

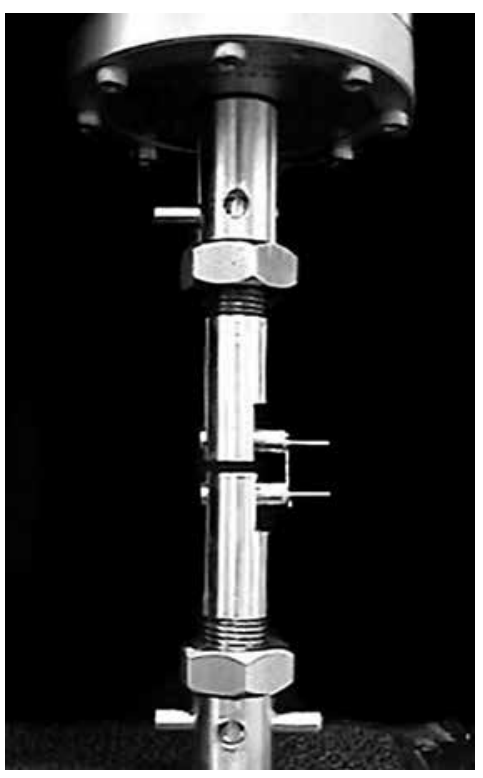

Figure 2 - Detail of the device attached to the universal testing machine with a fixed distance of $21 \mathrm{~mm}$ between the metallic rods. 
used to determine differences between groups in the time interval. To compare the averages two by two in the analyzed time, the Tukey test was used, complemented by the Scott-Knott test, to avoid ambiguity due to the large amount of time in the analysis. For both tests, $\mathrm{p} \leq 0.05$ was considered statistically significant.

\section{RESULTS}

The average values of the forces released by elastomeric chain group Am, Mo, Or and TP during the 35 days of the experiment are shown in Table 2. In general, the greater degradation of force occurred during the first day. From that on, the level of force continued to decrease, but slowly and gradually until the end of the third week. From the 21st to 35th days, there were no statistically significant changes $(\mathrm{p} \leq 0.05)$ in the force release.

At the end of the experiment, elastomers from the TP Group had the highest average force $(148.5 \mathrm{~g})$ it was statistically significant $(\mathrm{p} \leq 0.05)$ when compared to groups Am, Mo and Or. However, it's noted that the average initial force of the TP Group was also higher than the other groups.

It was noticed that on the first day of evaluation, there was no difference between groups, but this feature did not stand, for example, within one assessment week the average force is equal between the groups Am, Mo, Or and differ from the TP group, which is maintained up to 28 days of evaluation.
Given the initial force discrepancy of TP Group and to facilitate the understanding, the force degradation was also examined as a percentage of the initial strength in each time interval, irrespective of the initial value of the force in grams (Table 3). Considering that in the beginning, the absolute force values amounted to 100\%. The data showed that after $1 \mathrm{~h}$, the percentage of strength remaining ranged between 59\% to $69 \%$, ending up at the end of the first day with values in the order $45 \%$ to $50 \%$. The remaining force found in day 21 st was $40-45 \%$ depending on the group. At the end of the experiment, groups TP and Or had the highest percentage of force remaining, with no differences between them, while the lowest percentage of initial force were found in groups Mo and Am. There was no statistically significant difference between the groups Mo and Am.

\section{DISCUSSION}

The specification of the polyurethane used as raw material in the processing of elastomeric chains is not provided by the manufacturer, therefore the physical properties of these materials is only available through published studies. ${ }^{2,4,6,7,11,14,16,20,21,22}$

The frequency and diversity in the methodology of these studies provides the clinician an important parameter of quality, perhaps the only one, supplying data to make the best choice in purchasing the product, among the many trademarks, and once that is in clinical use, to know the physical behavior of the material you are using.

Table 2 - Mean (g) and standard deviation of the forces in each time period of four groups tested.

\begin{tabular}{|c|c|c|c|c|}
\hline & $\begin{array}{c}\text { Am } \\
\text { mean } \pm \text { SD }\end{array}$ & $\begin{array}{c}\text { M॰ } \\
\text { mean } \pm \text { SD }\end{array}$ & $\begin{array}{c}\text { Or } \\
\text { mean } \pm \text { SD }\end{array}$ & $\begin{array}{c}\text { TP } \\
\text { mean } \pm \text { SD }\end{array}$ \\
\hline Initial & $307.2 \pm 5.6^{\mathrm{a}, \mathrm{E}}$ & $298.7 \pm 4,5 \mathrm{a}, \mathrm{G}$ & $296.2 \pm 4.2^{a, F}$ & $373.3 \pm 42.0 \mathrm{~b}, \mathrm{G}$ \\
\hline 1 hour & $185.5 \pm 9.6^{\mathrm{a}, \mathrm{D}}$ & $204.7 \pm 9.0$ b.F & $182.7 \pm 7.3^{\mathrm{a} . \mathrm{E}}$ & $220.4 \pm 31.7$ c.F \\
\hline 3 hours & $165.7 \pm 8.5^{a, C}$ & $188.6 \pm 5.4^{b, E}$ & $170.0 \pm 6.2^{\mathrm{a}, \mathrm{D}}$ & $202.0 \pm 30.7 \mathrm{c}, \mathrm{E}$ \\
\hline 5 hours & $161.0 \pm 6.7^{a} \mathrm{ac}$ & $176.0 \pm 7.5^{b, D}$ & $169.5 \pm 6.9 a b, D$ & $188.9 \pm 29.5$ \\
\hline 7 hours & $158.0 \pm 6.2^{a, c}$ & $169.3 \pm 6.7^{a b, D}$ & $157.3 \pm 6.1^{\mathrm{a}, \mathrm{c}}$ & $175.0 \pm 28.6^{b, c}$ \\
\hline 9 hours & $148.1 \pm 6.4 \mathrm{ab}, \mathrm{B}$ & $154.5 \pm 6.9 b . c$ & $140.2 \pm 5.5 \mathrm{a.B}$ & $157.8 \pm 28.3^{b, A}$ \\
\hline 1 day & $142.1 \pm 5.1^{a, B}$ & $143.5 \pm 5.8^{\mathrm{a}, \mathrm{B}}$ & $143.1 \pm 4.4^{\mathrm{a}, \mathrm{B}}$ & $152.0 \pm 27.8^{\mathrm{a} . \mathrm{A}}$ \\
\hline 7 days & $146.4 \pm 4.9 a b . B$ & $144.8 \pm 6.1^{\mathrm{a}, \mathrm{B}}$ & $158.0 \pm 5.1 b^{c, c}$ & $170.4 \pm 25.6 \mathrm{ccc}$ \\
\hline 14 days & $139.6 \pm 3.5 a b . B$ & $136.7 \pm 5.0$ & $149.9 \pm 6.0^{b . B}$ & $162.8 \pm 26.1 \mathrm{c,B}$ \\
\hline 21 days & $127.2 \pm 4.7^{a b . A}$ & $118.3 \pm 3.9^{a, A}$ & $135.0 \pm 4.3^{b . A}$ & $150.9 \pm 25.1 \mathrm{c.A}$ \\
\hline 28 days & $123.6 \pm 4.2^{a b, A}$ & $118.4 \pm 5.1^{\mathrm{a}, \mathrm{A}}$ & $135.2 \pm 5.7^{\mathrm{b}, \mathrm{A}}$ & $148.3 \pm 24.5^{c . A}$ \\
\hline 35 days & $127.0 \pm 9.2^{\mathrm{a} . \mathrm{A}}$ & $122.0 \pm 6.2^{\mathrm{a}, \mathrm{A}}$ & $132.3 \pm 4.9^{\mathrm{a} . \mathrm{A}}$ & $148.5 \pm 22.7^{b . A}$ \\
\hline
\end{tabular}

In the rows, means followed by same lowercase letters do not differ significantly ( $p>0.05)$ by Tukey test. In columns, means followed by same capital letters do not differ significantly $(p>0.05)$ by Scott-Knott test. 
The optimal force required for space closure in orthodontics is controversial. Ren et $\mathrm{al}^{19}$ published a meta-analysis study of optimal force for tooth movement and concluded that there is no scientific evidence as to recommend the optimal force level in orthodontic practice. The few studies in humans suggest that the magnitude of force required for the body movement of the canines ranging from 100 to $350 \mathrm{~g}$ for mechanics with friction and approximately $60 \mathrm{~g}$ mechanical friction-free. ${ }^{19}$ In the present work an initial force of approximately $300 \mathrm{~g}$ was selected because according to the literature, ${ }^{1,4,14,21,23}$ during the first 24 hours the highest rate of force decay would occur (ranging from $45 \%$ to $75 \%$ ), and thus the remaining force level would be consistent with the movement of the canines.

Commonly, orthodontic consultations occur every 3 or 4 weeks, when the replacement of the elastomeric chain happens. Thus, most studies ${ }^{2,12,21}$ evaluated the behavior of these materials for a period of 28 days. However, the return of the patient, in certain cases may be in a larger interval. Therefore, this study evaluated the behavior of elastic chains for five weeks, to complement the data already existing in the literature.

The null hypothesis that the elastomeric ligatures remain dimensionally stable and do not lose strength during the stretch was rejected based on the results of this experiment.

The behavior of the elastomers in groups Am, Mo, Or, and TP during the first 9 hours and 5 weeks of this experiment can be seen in Figures 3 and 4. All the samples showed a similar degradation curve, varying only in intensity according to the tested group.

The results demonstrated that the highest level of force degradation occurred during the first day of the experiment, especially in the first hour in all groups (Table 3, Figs 3 and 4), which is in agreement with other studies. ${ }^{1,3,9,12,14,23,24}$

In general, the initial loss of strength during the first hour ranged from 31 to $41 \%$. In the first 24 hours the loss of strength was between 50 and 55\% (Table 3, Fig 4). The literature reports similar results with a decrease of strength ranging from 50\% to $75 \%$ during the first day. ${ }^{1,4,14,21,23}$ From the first 24 hours on, the level of force continued to decrease, but slowly and gradually until the third week, where it remained almost constant. Because of this, it seems prudent to pre-stretch the elastomeric chains prior to clinical application.

The fact that the TP group has shown the highest average ultimate force (148 g) probably happened because the group had the greatest force at the beginning when compared to other groups. In addition, TP group showed the highest average of the initial forces, differing from the other groups $(p \leq 0.05)$, and a great variability in the values of these forces at the beginning, which was evidenced by the large standard deviation (42 g) groups when compared to the groups Am (5.6 g), Mo (4.5 g) and Or (4.2 g).

\begin{tabular}{|c|c|c|c|c|}
\hline & $\begin{array}{c}\text { Am } \\
\text { mean } \pm \text { SD }\end{array}$ & $\begin{array}{c}\text { Mo } \\
\text { mean } \pm \text { SD }\end{array}$ & $\begin{array}{c}\text { Or } \\
\text { mean } \pm \text { SD }\end{array}$ & $\begin{array}{c}\mathrm{TP} \\
\text { mean } \pm \mathrm{SD}\end{array}$ \\
\hline Initial & $100 \%$ & $100 \%$ & $100 \%$ & $100 \%$ \\
\hline 1 hour & $59 \pm 3^{a}$ & $69 \pm 3^{c}$ & $63 \pm 3^{b}$ & $66 \pm 9 b$ \\
\hline 3 hours & $53 \pm 3^{a}$ & $63 \pm 2^{c}$ & $59 \pm 2^{b}$ & $60 \pm 9^{b}$ \\
\hline 5 hours & $51 \pm 2^{a}$ & $59 \pm 3^{b}$ & $59 \pm 2^{b}$ & $56 \pm 9^{b}$ \\
\hline 7 hours & $50 \pm 2^{a}$ & $57 \pm 2^{b}$ & $55 \pm 2^{b}$ & $52 \pm 9^{a}$ \\
\hline 9 hours & $47 \pm 2^{a}$ & $52 \pm 2^{b}$ & $49 \pm 2^{a}$ & $47 \pm 8^{a}$ \\
\hline 1 day & $45 \pm 2^{a}$ & $48 \pm 2^{b}$ & $50 \pm 2^{b}$ & $45 \pm 8^{a}$ \\
\hline 7 days & $47 \pm 2^{a}$ & $49 \pm 2^{a}$ & $55 \pm 2^{c}$ & $51 \pm 8^{b}$ \\
\hline 14 days & $44 \pm 1^{a}$ & $46 \pm 2^{a}$ & $52 \pm 2^{c}$ & $48 \pm 8^{b}$ \\
\hline 21 days & $40 \pm 2^{a}$ & $40 \pm 1^{a}$ & $47 \pm 1^{b}$ & $45 \pm 7^{b}$ \\
\hline 28 days & $39 \pm 1^{a}$ & $40 \pm 2^{a}$ & $47 \pm 2^{b}$ & $44 \pm 7^{b}$ \\
\hline 35 days & $40 \pm 3^{a}$ & $41 \pm 2^{a}$ & $46 \pm 2^{b}$ & $44 \pm 7^{b}$ \\
\hline
\end{tabular}

In the rows, mean followed by the same letters do not differ significantly ( $p>0.05)$ by Scott-Knott test. 


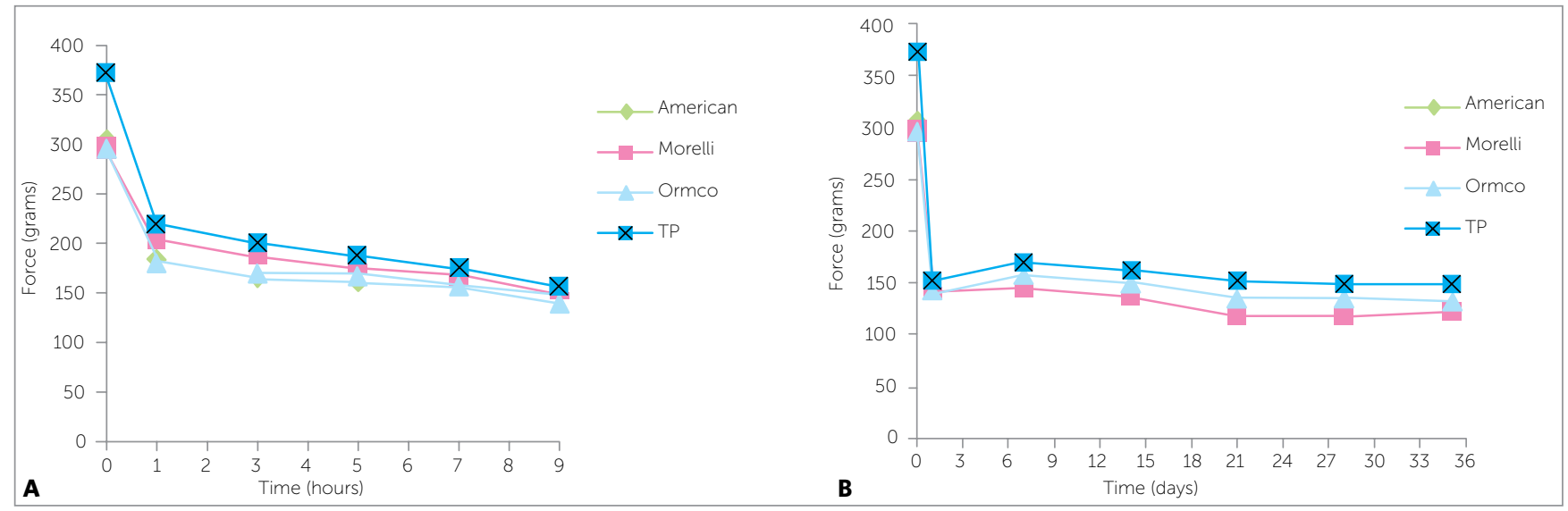

Figure 3 - A) Force degradation in the first 9 hours. B) Force degradation during 35 days of the experiment.

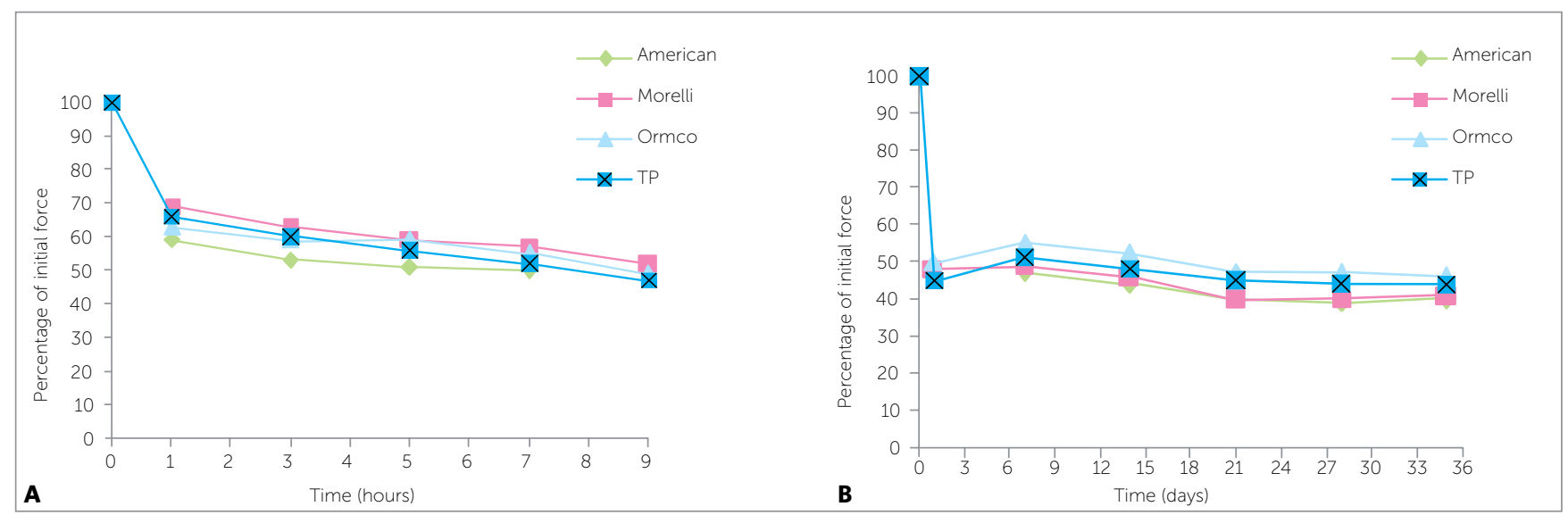

Figure 4 - A) Percentage of initial force during the first 9 hours. B) Percentage of the initial force during 35 days of the experiment.

It is important to mention that even using elastomeric chains with similar characteristics, i.e. number of links, cut by the same operator, stretched the same distance for the same period of time, elastomers from TP Group showed great variability in initial force values ( $300 \mathrm{~g}$ to $434 \mathrm{~g}$ ). Similar findings were found in another study, where we observed standard deviation of $39.5 \mathrm{~g}$ of the initial forces in elastomers from TP Orthodontics. ${ }^{12}$

Groups Or and TP showed the same amount of force decay in percentage terms, from the beginning to the end of the experiment. Thus, although the Group TP had larger initial and final strength, when compared to Oregon, there was no statistical difference in the amount of force decay in proportion to their initial strength (Table 3).
De Genova et $\mathrm{al}^{6}$ found on the 21 st day of the study, percentages of remaining force of Ormco elastomers (39\%) and TP Orthodontics (49\%) who keep similar to those found in the present work, where the values for the group Or were 47\% and Group TP of $45 \%$. However, Jossel et $\mathrm{al}^{12}$ found a higher percentage of force remaining on the 28th day (TP 78\%, 68\% Ormco; American 58\%) than those found in this study, possibly because of the methodology used by the authors, the elastomers were maintained in room temperature and not at $37^{\circ} \mathrm{C}$, which may have contributed to the decreased strength deterioration.

The results showed that by the end of the experiment, groups TP and Or had the highest percentage of initial force while Mo and Am groups had the lowest. No statistical difference in the percentage of 
initial force was demonstrated, between the groups Mo and Am at the end of the evaluation. However, it should be considered that the samples of the Mo Group stretched only 20\% of its original length while the Am Group was drawn at 44.8\% (Table 1). According to the literature, ${ }^{25}$ the greater the stretching, the greater the deterioration of the strength. The smallest stretch, and consequently lower plastic deformation of Mo Group sample compared to the Am Group sample, may have contributed to the similar performance between these groups. Therefore, Morelli's elastomeric chains that stretch above 20\% may have further deterioration of strength.

In the study by Araujo and Ursi, ${ }^{2}$ initial forces were used ranging from 178 to $249 \mathrm{~g}$ whereas in the present work initial forces from 296 to $374 \mathrm{~g}$ were used. The use of lower initial forces may have contributed to the authors finding less degradation of strength. However, elastomers creating lower initial forces, although under less degradation, tend to produce lower final strengths. After four weeks the absolute values of force obtained by Araújo and Ursi² (Morelli 72 g, Ormco 68 g, TP $114 \mathrm{~g}$ ) were lower than those found in this study (Morelli 118g, Ormco 135g, TP 148g). Considering that both studies were performed in vitro, where there is less degradation of force in the oral cavity, ${ }^{3}$ it is questioned whether lower forces would be clinically compatible with canine tooth movement.

Measuring the clinically used force of an elastomer with a precision instrument is strongly advisable when using any commercial brand. In the case of TP Orthodontics elastomers, the high standard deviation does not disqualify it for clinical use, because the degradation of force standard is similar when compared to the other ones tested, but the difference of the initial strength with the same number of links is mandatory for measurement in all its clinical application.

Therefore, since the raw material used and the manufacturing process of the elastomer is not available, it is important to know the theoretical material published in the literature and to measure routinely the applied force.

\section{CONCLUSION}

Based on the results of this study, it can be concluded that: There was a force degradation over time in all groups, being greatest on the first day of the experiment, especially in the first hour; From the third to the fifth week there was no noticeable force degradation in either group; By the end of the experiment, the brands Ormco and TP Orthodontics showed the highest percentage of remaining force. 


\section{REFERENCES}

1. Andreasen GF, Bishara S. Comparison of alastik chains to elastics involved with intra-arch molar-to-molar forces. Am J Orthod. 1971;60(2):200-1

2. Araujo FB, Ursi WJ. Estudo da degradação de força gerada por elásticos ortodônticos sintéticos. Rev Dental Press Ortod Ortop Facial. 2006:11(6):52-61.

3. Ash JL, Nikolai RJ. Relaxation of orthodontic elastomeric chains and modules in vitro and in vivo. J Dent Res. 1978;57(5-6):685-90.

4. Baty DL, Storie DJ, von Fraunhofer JA. Synthetic elastomeric chains: a literature review. Am J Orthod Dentofacial Orthop. 1994;105(6):536-42.

5. Billmeyer FW. Textbook of polymer science. 3rd ed. New York: John Wiley \& Sons; 1984

6. De Genova DC, McInnes-Ledoux P, Weinberg R, Shaye R. Force degradation of orthodontic elastomeric chains: a product comparison study. Am J Orthod. 1985:87(5):377-84.

7. Eliades T, Eliades G, Silikas N, Watts DC. In vitro degradation of polyurethane orthodontic elastomeric modules. J Oral Rehabil. 2005:32(1):72-7

8. Ferriter JP, Meyers CE Jr, Lorton L. The effect of hydrogen ion concentration on the force-degradation rate of orthodontic polyurethane chain elastics. Am J Orthod Dentofacial Orthop. 1990;98(5):404-10.

9. Hershey HG, Reynolds WG. The plastic module as an orthodontic toothmoving mechanism. Am J Orthod. 1975;67(5):554-62

10. Huget EF, Patrick KS, Nunez LJ. Observations on the elastic behavior of a synthetic orthodontic elastomer. J Dent Res. 1990;69(2):496-501.

11. Jeffries $\mathrm{CL}$, von Fraunhofer JA. The effects of $2 \%$ alkaline glutaraldehyde solution on the elastic properties of elastomeric chain. Angle Orthod. 1991;61(1):25-30.

12. Josell SD, Leiss JB, Rekow ED. Force degradation in elastomeric chains. Semin Orthod. 1997:3(3):189-97

13. Kovatch JS, Lautenschlager EP, Apfel DA, Keller JC. Load extension time behavior of orthodontic alastiks. J Dent Res. 1976:55(5):783-6.
14. Lu TC, Wang WN, Tarng TH, Chen JW. Force decay of elastomeric chain - a serial study. Part II. Am J Orthod Dentofacial Orthop. 1993:104(4):373-7.

15. Matta ENR, Chevitarese $O$. Avaliação laboratorial da força liberada por elásticos plásticos. Rev SBO. 1997:3(4):131-6.

16. Matta ENR, Chevitarese $O$. Deformação plástica de elásticos ortodônticos em cadeia: estudo in vitro. Rev SOB. 1998;3(5):188-92

17. Morton M. Rubber technology. 3rd ed. Londres: Chapman \& Hall; 1995.

18. Nattrass C, Ireland AJ, Sherriff M. The effect of environmental factors on elastomeric chain and nickel titanium coil springs. Eur J Orthod. 1998:20(2):169-76

19. Ren Y, Maltha JC, Kuijpers-Jagtman AM. Optimum force magnitude for orthodontic tooth movement: a systematic literature review. Angle Orthod. 2003;73(1):86-92.

20. Stevenson JS, Kusy RP. Force application and decay characteristics of untreated and treated polyurethane elastomeric chains. Angle Orthod 1994;64(6):455-64.

21. Taloumis LJ, Smith TM, Hondrum SO, Lorton L. Force decay and deformation of orthodontic elastomeric ligatures. Am J Orthod Dentofacial Orthop. 1997:111(1):1-11

22. Teixeira L, Pereira B do R, Bortoly TG, Brancher JA, Tanaka OM, GuarizaFilho $O$. The environmental influence of Light Coke, phosphoric acid, and citric acid on elastomeric chains. J Contemp Dent Pract. 2008;9(7):1724

23. von Fraunhofer JA, Coffelt MT, Orbell GM. The effects of artificial saliva and topical fluoride treatments on the degradation of the elastic properties of orthodontic chains. Angle Orthod. 1992;62(4):265-74

24. Wong AK. Orthodontic elastic materials. Angle Orthod. 1976;46(2):196-205.

25. Young J, Sandrik JL. The influence of preloading on stress relaxation of orthodontic elastic polymers. Angle Orthod. 1974;49(2):104-9. 